\title{
FISCAL DECENTRALIZATION AND GENDER EQUALITY IN DEVELOPING ECONOMIES: DYNAMICS OF INCOME GROUPS IN ECONOMIES AND CORRUPTION
}

\author{
Sidra Naeem ${ }^{1+}$ \\ Rana Ejaz Ali Khan²
}

\author{
${ }^{1,2}$ Department of Economics, The Islamia University of Bahawalpur, \\ Bahawalpur, Pakistan.
}

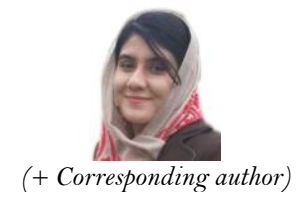

ABSTRACT

\section{Article History \\ Received: 8 March 202 Revised: 17 July 202 \\ Accepted: 19 August 2021 \\ Published: 13 September 202}

\section{Keywords}

Fiscal decentralization

Gender equality index

Corruption.

JEL Classification:

$\mathrm{H} 71, \mathrm{H} 50, \mathrm{~J} 16$
A large number of studies on fiscal decentralization have supported the claim that decentralized governments have a greater capacity to approach local preferences and have greater potential for public service delivery, which demonstrates a favorable status of socioeconomic indicators. However, there is no empirical evidence on fiscal decentralization and gender equality. This study empirically examines the effect of fiscal decentralization on gender equality in 29 developing economies from 2006 to 2020 by employing the dynamic panel system generalized method of moments (GMM). The study uses three measures of fiscal decentralization-expenditure, revenue, and composite decentralization - to learn the dynamics of income groups in developing economies, and corruption from the perspective of fiscal decentralization and gender equality. The results demonstrate that fiscal decentralization improves gender equality in the sample of developing economies as well as in the sub-sample of developing economies, i.e., lower-middle income countries and upper-middle income countries subject to the control of corruption, otherwise fiscal decentralization may devastate gender equality in developing economies and upper-middle income economies. Corruption plays a dynamic role in the relationship between fiscal decentralization and gender equality. The desired results of fiscal decentralization may be attained through policy reforms to control corruption. The dynamics of income groups in the sampled economies also have implications for the relationship between fiscal decentralization and gender equality.

Contribution/Originality: The literature on the impact of fiscal decentralization has focused on a variety of socioeconomic indicators, but none of the studies has examined the impact of fiscal decentralization on gender disparity. The current study contributes to the literature by examining this aspect for developing economies.

\section{INTRODUCTION}

Fiscal decentralization has been growing globally since the 1990s. The rationality behind fiscal decentralization is efficiency and accountability, which lead to the general welfare of an economy. The accountability of small units is easier to manage than the bigger ones, so decentralization provides a good scope for accountability and closely matches the delivery of public goods and desires of citizens, hence more efficiency gains may be attained (Oates, 1993; Oates, 1999). More efficiency gains are also argued on the grounds that local governments are in close proximity to communities, so public services and goods can be provided as per the preferences and at lesser cost (Blais, Anduiza, \& Gallego, 2011). On the other hand, it is argued that local governments are less capable of 
providing public services at local levels. There are certain problems with local and subnational governments, like lower administrative capacity at the local level, Leviathan governments (Ivanyna \& Shah, 2011), low investment in innovation and technology (Prud'Homme, 1995), and corruption (Brueckner, 2000), so the benefits of decentralization may remain weakened (Weingast, 2014). Treisman (2000) argued that fiscally and politically more decentralized states suffer from macroeconomic instability. Koethenbuerger \& Lockwood (2010) pointed out some conditions which may decrease economic growth as a consequence of fiscal decentralization. Atisa, Zemrani, \& Weiss (2021) narrated that decentralization misses the triple-bottom line of sustainability comprised of economic, social, and environmental prosperity.

Gender equality is an important development objective and it is closely linked to economic development (Duflo, 2012). On the measurement aspect of gender equality, existing literature contains a variety of definitions alternative to gender equality. Sen (2000) draws a broader definition of inequality focusing on capabilities. Inequality in general and gender inequality in particular limit the opportunities an individual or a group of individuals have available to them. Equality is defined as expanding freedoms, opportunities, and valued outcomes without considering gender (Nussbaum, 2011; Sen, 2000).

Theoretically, fiscal decentralization may affect the gender disparity based on procedure, legal framework, and the socio-political norms of economies ${ }^{1}$. From the procedural aspect, the extent of the components of fiscal decentralization (i.e., revenue and expenditure related to the male and female community of the local government's jurisdictions) is covered. The legal aspect covers whether the legislation of a country covers gender-based budgeting or not and whether the legal framework has provisions for independent female decision-making regarding political processes. The socio-political aspect is also linked to fiscal decentralization and gender disparity. In some economies, socio-political systems possibly negate the rights of women, particularly in the areas of health, education, employment, and empowerment. Similarly, the economic social systems may have different environments regarding women's awareness, decision-making, exposure to media, and participation in political and economic activities. Keeping in view all three aspects, related to varying situations of interaction of fiscal decentralization and gender disparity ${ }^{2}$ in different economies, it would be better to see the issue of fiscal decentralization and gender equality in a panel of developing economies.

Many studies have investigated the effects of fiscal decentralization on different indicators, such as health (Asfaw, Frohberg, James, \& Jütting, 2008; Cantarero \& Pascual, 2008; Faguet, Khan, \& Kanth, 2021), education (Asfaw et al., 2008; Busemeyer, 2008; Stotsky, Chakraborty, \& Gandhi, 2019), employment (Martinez-Vazquez \& Yao, 2009), income inequality (Rodriguez-Pose, Tomaney, Pike, Torrisi, \& Tselios, 2011; Sepulveda \& MartinezVazquez, 2011), economic growth (Ahmad, 2020; Cantarero \& Gonzalez, 2009; Nguyen \& Anwar, 2011; RodríguezPose \& Krøijer, 2009), economic freedom, political \& civil liberties, and accountability (Bojanic, 2018), global competitiveness (Chalil, 2020), environmental quality (Li et al., 2021), governance (Altunbaş \& Thornton, 2012), corruption (Alfada, 2019), and human development (Habibi et al., 2003; Soejoto, Subroto, \& Suyanto, 2015). However, conceptually, it may be assumed that fiscal decentralization affects gender equality based on the assumption that it may affect the male- and female-related indicators differently. For instance, fiscal decentralization may strongly affect the education of males but weakly affect the education of females. This may also be the case for health, human capital, income generation, civil liberties, and employment. For instance, fiscal decentralization may affect the general health outcomes effectively, but maternal health indicators may not be

\footnotetext{
${ }^{1}$ The other aspect of fiscal decentralization and gender disparity is that in the process of decentralization (administrative, political, and fiscal) gender disparity exists, particularly in the entity of political decentralization, which may cause gender disparity in the outcome of socioeconomic indicators.

${ }^{2}$ Khan (2011) developed a theoretical framework showing that political decentralization may affect women's empowerment. This framework sketches the relationship between fiscal decentralization and gender equality, as political decentralization and fiscal decentralization go side by side and female empowerment is logically linked with gender equality.
} 
affected efficiently. Literature has evidenced that socioeconomic and micro and macroeconomic indicators affect gender-related indicators differently. For instance, Thomson et al. (2018) found that health policies affect male and female health differently in high-income countries. From this type of evidence, the question emerges whether fiscal decentralization has varying effects on the health, employment, and education of men and women, i.e., whether it increases or decreases gender equality. The foremost objective of the current study is to determine the effect of fiscal decentralization on gender equality in developing economies.

Previous literature has evidenced that the impact of fiscal decentralization on socioeconomic indicators may differ in income and regional groups of economies (Bojanic \& Collins, 2021; Cavusoglu \& Dincer, 2015; RodríguezPose \& Ezcurra, 2010). Rodriguez-Pose et al. (2011) concluded that fiscal decentralization has varying effects on income inequality in developed and comparatively lesser developed regions of Europe. Jalil, Feridun, \& Sawhney (2014) evidenced that fiscal decentralization has shown a stronger effect on economic growth in wealthy regions compared to poor regions in China. Do the income groups in economies matter in the implications of fiscal decentralization in gender equality? To answer this question the current study makes a comparison of upper-middle income and lower-middle income developing economies. Literature has provided varying evidence on the role of corruption in the benefits of fiscal decentralization. For instance, Chalil (2020) evidenced that fiscal decentralization positively impacts global competitiveness in countries with low levels of corruption but adversely in countries with high levels of corruption. Similarly, Nguyen, Thuy, Duc, \& Vu (2020) established that a country's fiscal decentralization should be linked to control of corruption to improve the income inequality among the regions. Thus, the dynamic of corruption was also incorporated into the current study.

This study departs from the existing literature in four ways. First, in the earlier literature, none of the studies focused on the gender implications on fiscal decentralization ${ }^{3}$. Second, gender equality may vary in different economies depending on their socioeconomic dynamics along with cultural and religious implications. Therefore, gender equality in the perspective of fiscal decentralization may vary for groups within the economies. To have a comprehensive explanation of the influence of fiscal decentralization on gender equality, the current study focuses on the developing economies and income groups of developing economies, i.e., lower-middle and upper-middle income countries. This ensures robust results that are generally accepted. Third, a more comprehensive measure of gender equality may be the gender equality index. It covers disparity in education, health, employment, and empowerment. The gender equality index was used in this study instead of gender equality as a single socioeconomic indicator, as per the study by Stotsky et al. (2019) on India. Fourth, the dynamics of the income groups in the economies and corruption in the perspective of the role of fiscal decentralization in gender equality is the distinguished feature of the current study. Thus, in the literature on gender equality, the current study is not only an addition to the perspective of fiscal decentralization but also includes the use of the gender disparity index, the dynamics of income groups in the economies, and corruption, which distinguish it from the existing literature.

\section{LITERATURE REVIEW}

There is plenty of literature about the encouraging effects of fiscal decentralization on different socioeconomic indicators in developed and developing economies, for example, education and health (Faguet et al., 2021 ; Stotsky et al., 2019), human development (Soejoto et al., 2015), financial development (Wang, Liu, Adebayo, Lobon, \& Claudia, 2021), and economic growth (Malik \& Hussain, 2006). However, some of the studies have found negative effects of fiscal decentralization, for instance, it hampers economic growth (Baskaran \& Feld, 2013), deteriorates health outcomes (Cantarero \& Pascual, 2008; Rubio, 2011), does not increase gender equality in education (Stotsky et al., 2019), and reduces accountability and increases corruption (Fan, Lin, \& Treisman, 2009). Koethenbuerger \&

\footnotetext{
${ }^{3}$ Stotsky et al. (2019) examined the effect of intergovernmental fiscal transfers on gender equality in education in India. Bianchi, Giorcelli, \& Martino (2021) investigated the effect of fiscal decentralization on female employment in Italian municipalities.
} 
Lockwood (2010) pointed out some situations where fiscal decentralization may decrease economic growth. However, the relevant literature, particularly the studies that cover the implications of fiscal decentralization on indicators that may have gender aspect, were reviewed for this study.

In earlier studies, Tiebout (1956) suggested the theory of local expenditures and that the size of a country has a very important place in the process of decentralization. Larger countries may be exploited in the provision of services at local levels. The regions further away from the center may be poorly served because of transportation cost, ethnic background of the region, preferences, and poor information. Oates (1993) argued that the goods and services provided in decentralized setups across the regions receive more welfare than provided by the central governments. Qian \& Weingast (1997) proposed a new perspective in federalism in which jurisdictional competition along with decentralization might be a more efficient way to increase the regional equality rather than a centrally authorized allocation. They also suggested that some federalisms might be self-sustaining.

In recent literature, empirical evidence has emerged. For instance, Asfaw et al. (2008) examined the decentralization and health outcomes in rural India. They used a factor analysis of three variables, i.e., the share of local revenue of the total local expenditure, the total local expenditure per rural population, and the share of local (rural) expenditure of the total state expenditure (intermediate government tier) to measure the fiscal decentralization. The results suggested that decentralization could help to reduce the rural infant mortality rates. Furthermore, efficiency of fiscal decentralization can be attained through political decentralization. Paramita, Yamazaki, Setiawati, \& Koyama (2018) found that health care decentralization tends to increase equal distribution of health inputs. Faguet et al. (2021) also found that decentralization improves the performance of public health and education sectors in Ethiopia. It also raises the enrollment rates in schools and the coverage of antenatal care. However, Rubio (2011) and Cantarero \& Pascual (2008) found an inverse association between fiscal decentralization and health effects in regions of Canada and Spain. However, all of these studies omitted the gender aspect of decentralization.

Rodriguez-Pose et al. (2011) studied the effect of decentralization on income inequality with the mediating role of economic development by using a panel of 102 regions from 13 countries in the European Union. They found that more fiscal decentralization lowers the per capita income inequality; however, the effect declines with an increase in regional income and a further increase in decentralization. Moreover, fiscal decentralization works more effectively in developed regions. Political decentralization has a weaker association with income inequality.

Altunbaş \& Thornton (2012) investigated the effect of fiscal decentralization on governance by examining data on 64 developed and developing economies. They found that in the existence of vertical administrative decentralization, the progressive influence of fiscal decentralization on corruption decreases. Jalil et al. (2014) empirically examined the relationship between fiscal decentralization and economic growth in the provinces of China. The study constructed a new composite indicator of fiscal decentralization containing five different financial variables and used it in the models along with standard measures of fiscal decentralization, which are commonly used. The study showed that there is a positive and strong correlation between fiscal decentralization and economic growth in the majority of the provinces. The impact of fiscal decentralization in wealthy provinces was found to be stronger compared to the poor provinces. However, Ahmad (2020) concluded that fiscal decentralization is not sufficient for economic growth and pointed out that the way decentralization is implemented is important. Li et al. (2021) concluded that expenditure decentralization in Pakistan has asymmetric effects on economic growth, while revenue decentralization has symmetric effects on economic growth. Soejoto et al. (2015) investigated the effect of fiscal decentralization on human development in Indonesia. The study used primary and secondary data to test the impact of funds decentralization on human development. The decentralization of funds has shown a positive impact on human development of each autonomous region and city. Habibi et al. (2003) examined the impact of decentralization on human development in Argentina's provinces. They concluded that the disparity of infant mortality rate and educational output among the low- and high-income provinces decreased during the period of 
decentralization. Bojanic (2018) investigated how fiscal decentralization affects economic freedom, accountability, and political and civil liberties in 12 American states. The study concluded that decentralization initially hinders but eventually increases accountability and political and civil liberties, but decentralization does not essentially lead to more economic freedom.Stotsky et al. (2019) examined the impact of intergovernmental fiscal transfers on gender parity in education measured by primary and secondary school enrolment in India. The results revealed that fiscal transfers from federal to state are not helpful in achieving gender equality in education in India. The study also used the disaggregate specification for transfers and grants and suggested that unconditional fiscal transfers strengthen gender equality but conditional transfers have little influence on gender equality in education.

Chalil (2020) investigated the impact of fiscal decentralization on global competitiveness and incorporated the level of corruption. The study found that fiscal decentralization enhances global competitiveness in less corrupt economies but it adversely affects the global competitiveness in highly corrupt economies.

Nguyen et al. (2020) used a balanced panel data set of Vietnam's 63 provinces and found a strong simultaneous relationship among fiscal decentralization, corruption, and income inequality. They suggested that control of corruption benefits fiscal decentralization. Bojanic \& Collins (2021) analyzed fiscal, administrative, and political decentralization on income inequality in the panel data of OECD and non-OECD countries. The study found that, overall, fiscal decentralization decreases income inequality. However, the effect diminishes and eventually reverses as economic development increases. The studies reviewed have attempted to discover the impact of fiscal decentralization on a number of socioeconomic indicators for individual countries as well as groups of economies. However, the gender equality aspect is yet to be investigated.

\section{METHODOLOGY}

\subsection{Model Specification}

A dynamic panel model was employed to test the impact of fiscal decentralization on gender equality in developing economies. This model uses the lag of the dependent variable as an independent variable, so the model has the capability of dynamic explanation. Usually, the dependent variable has a precise time inertia property. According to Blundell \& Bond (1998), the dependent variable is determined by its own previous conditions at different time periods (Bond, 2002). Generally, gender equality is a cultural phenomenon and it continues over a prolonged period. Conceptually, the current situation of gender equality is affected by its state in the former period. This can be clearly identified using a dynamic panel model. Panel data comprises many time dimensions, so additional evidence can be applied to examine the dynamic relationship. An endogeneity problem occurs because the lagged value of the dependent variable is associated with random errors of individual effects (Arellano \& Bond, 1991). To control this limitation, Arellano \& Bond (1991) offered a generalized method of moments (GMM), in which instrumental variables are employed to derive the parallel moment conditions. Furthermore, the system GMM model sums up the other estimation techniques, for instance, the maximum likelihood, two-stage least squares, and ordinary least squares (OLS). The current study uses the system GMM model for empirical analysis. The system GMM resolves the problem of weak instrumental variables more effectively, and hence controls the possible inaccuracies produced by difference GMM. This feature of the system GMM makes the estimation results more accurate (Arellano \& Bond, 1991). Also, the system GMM method can correct omitted variable bias, unobserved individual heterogeneity problems, potential endogeneity problems, and measurement errors, so that estimation results become robust. The Sargan test was employed to identify endogeneity, as it is observed that when instrumental variables are strictly exogenous, it uses the residuals to regress the instrumental variables. Principally, the $p$-value of the Sargan test should be greater than 0.1 indicating that the null hypothesis of the valid instrumental variables is accepted (Baum, Schaffer, \& Stillman, 2003). The system GMM model in this study is expressed in Equation 1.

$$
\mathrm{GEN}_{\text {it }}=\mathrm{f}\left(\mathrm{GEN}_{\mathrm{it}-1}, \mathrm{FD}_{\mathrm{it}}, \mathrm{X}_{\mathrm{it}}, \mu_{\mathrm{it}}\right)
$$


Where $\mathrm{I}=1 \ldots \ldots . \mathrm{N}$ and $\mathrm{t}=1 \ldots \ldots . \mathrm{T}$

FD is fiscal decentralization, GEN is gender equality, $\mathrm{X}_{\mathrm{it}}$ are other explanatory variables of the cross section in $\mathrm{t}$ time period, and $\mu_{\mathrm{it}}$ is the error term. The $\mathrm{i}$ and $\mathrm{t}$ represent countries and years, respectively. Fiscal decentralization is measured in three ways: expenditure decentralization, revenue decentralization, and composite decentralization. The system GMM models of gender equality for all three measures of fiscal decentralization are given in Equations 2,3 and 4 .

$$
\begin{aligned}
& \mathrm{GEN}=\alpha 0+\alpha \mathrm{GEN}_{\mathrm{it}-1}+\alpha 2 \mathrm{EXPD}_{\mathrm{it}}+\alpha 3 \mathrm{EXPD}^{*} \mathrm{COC}_{\mathrm{it}}+\alpha 4 \mathrm{GHEXP}_{\mathrm{it}}+\alpha 5 \mathrm{FEMPS}_{\mathrm{it}}+\alpha 6 \mathrm{LGDPE}+\varepsilon_{\mathrm{it}} \\
& \mathrm{GEN}=\beta 0+\beta \mathrm{GEN}_{\mathrm{it}-1}+\beta 2 \mathrm{REVD}_{\mathrm{it}}+\beta 3 \mathrm{REVD}^{*} \mathrm{COC}_{\mathrm{it}}+\beta 4 \mathrm{GHEXP}_{\mathrm{it}}+\beta 5 \mathrm{FEMPS}_{\mathrm{it}}+\beta 6 \mathrm{LGDPE}+\varepsilon_{\mathrm{it}} \\
& \mathrm{GEN}=\gamma 0+\gamma \mathrm{GEN}_{\mathrm{it}-1}+\gamma_{2} \mathrm{COMPD}_{\mathrm{it}}+\gamma 3 \mathrm{COMPD}^{*} \mathrm{COC}_{\mathrm{it}}+\gamma 4 \mathrm{GHEXP}_{\mathrm{it}}+\gamma 5 \mathrm{FEMPS}_{\mathrm{it}}+\gamma 6 \mathrm{LGDPE}+\varepsilon_{\mathrm{it}}
\end{aligned}
$$

Where:

GEN = gender equality, measured by the gender equality index.

$\mathbf{G E N}_{\mathrm{it}-1}=$ lag of dependent variable (gender equality).

EXPD = expenditure decentralization, measured by the expenditure decentralization ratio.

$(\mathrm{EXPD}=\mathrm{LE} / \mathrm{LE}+C E$, where $\mathrm{LE}$ and $\mathrm{CE}$ are the local expenditures and central expenditures, respectively. REVD = revenue decentralization, measured by the revenue decentralization ratio.

$(R E V D=\mathrm{L} R / \mathrm{L} R+C R$, where $\mathrm{LR}$ and $\mathrm{CR}$ are local revenues and central revenues, respectively.

COMPD = composite decentralization, measured by the composite ratio of expenditure decentralization and revenue decentralization $(\mathrm{COMPD}=\mathrm{REVD} / 1-\mathrm{EXPD})$, where $\mathrm{REVD}$ and $\mathrm{EXPD}$ are the ratio of revenue decentralization and the ratio of expenditure decentralization, respectively.

EXPD*COC $=$ expenditure decentralization*control of corruption (interaction term).

REVD*COC $=$ revenue decentralization* ${ }^{*}$ control of corruption (interaction term).

COMPD* $\mathbf{C O C}=$ composite decentralization*control of corruption (interaction term).

GHEXP = government health expenditure, measured by domestic general government health expenditure as a percentage of GDP.

FEMPS = female employment in service sectors, measured by female employment in services as a percentage of overall female employment.

LGDPE = GDP per capita, measured as a log of GDP per person at constant 2017 PPP \$.

$\boldsymbol{\varepsilon}=$ error term.

\subsection{Defining the Variables}

3.2.1. Gender Equality

Gender equality is measured by the gender equality index, as described in the Global Gender Gap Report. This index observes the gap between women and men in four important categories: health and survival, educational attainment, economic participation and opportunity, and political empowerment. The measure is constructed from four sub-indices, i.e., economic participation and opportunity ratio, educational attainment ratio, health and survival ratio, and political empowerment ratio, along with 14 indicators. The highest possible score in all sub-indices is one (equality) and the lowest score is zero (inequality); an unweighted average of sub-indices scores generates the Global Gender Equality Index.

\subsubsection{Expenditure Decentralization}

The current study measured expenditure decentralization as a ratio that is the share of expenditures (i.e., the sum of expense and net investment in non-financial assets) of the different levels of government (central, state/province/region, and local) as a proportion of general government spending. The measure excludes the portion of spending that is transferred to other levels of government, international organizations, and foreign governments. The indicator in the database is computed as follows: 


\section{Expenditure decentralization $=X G$ own spending $/ G G$ spending}

Where, XG represents a given level of government (central, state/province/region, or local) and GG is the general government. Own spending excludes the portion of expenditures transferred to other government units, foreign governments, and international organizations. In this study, we use expenditure at local level, so the expenditure decentralization is calculated as follows:

\section{$\mathrm{EXPD}=\mathrm{LE} / \mathrm{L} E+C E$}

This measure has also been used in a number of studies (Cantarero \& Gonzalez, 2009; Lin \& Liu, 2000; Neyapti, 2010; Xie, Zou, \& Davoodi, 1999; Zhang \& Zou, 1998). Based on the theoretical background of the implications of fiscal decentralization, it is hypothesized that expenditure decentralization increases gender equality in developing economies.

\subsubsection{Revenue Decentralization}

Revenue decentralization ratio is measured by the share of own revenues of the levels of government as a proportion of general government revenue. Own revenues exclude the portion of revenues obtained from other levels of government or from non-resident governments and international organizations. The tax revenue ratio is calculated as the share of a specified level of government tax revenues to general government tax revenue, as shown below:

\section{Revenue decentralization $=X G$ own revenue $/ G G$ revenue}

Where, XG represents a specified level of government (central, state/province/region, or local) and GG represents general government. Own revenue excludes the portion of revenue received as transfers from other government units, foreign governments, and international organizations.

\section{$R E V D=\mathrm{L} R / \mathrm{L} R+C R$}

This calculation has also been frequently used in the literature (Akai \& Sakata, 2002; Cantarero \& Gonzalez, 2009; Feltenstein \& Iwata, 2005; Iimi, 2005) ${ }^{4}$. It is speculated that revenue decentralization boosts gender equality in developing economies.

\subsubsection{Composite Decentralization}

Martinez-Vazquez \& McNab (2003) stated that fiscal decentralization measures used in the literature are based on a single dimension of fiscal decentralization, i.e. expenditure decentralization or revenue decentralization, but fiscal decentralization is a multidimensional phenomenon, so a multidimensional measure is required to give an accurate picture of decentralization. Martinez-Vazquez \& Timofeev (2009) developed a composite indicator of fiscal decentralization, which captures the multidimensionality nature of fiscal decentralization. It essentially combines the information contained in expenditure and revenue ratios.

\section{$\mathrm{COMPD}=\mathrm{REVD} / 1-\mathrm{EXPD}$}

Where, COMPD, REVD, and EXPD represent composite decentralization, revenue decentralization, and expenditure decentralization, respectively. A number of studies have also used this measure (e.g., Iqbal, Din, \& Ghani, 2012). It is assumed that this measure is suitable to analyze the impact of fiscal decentralization on gender equality. However, some other composite decentralization indices have also been used in the literature (Asfaw et al., 2008; Jalil et al., 2014) $)^{5}$. It is speculated that composite decentralization increases gender equality in developing economies.

\footnotetext{
${ }^{4}$ Ahmad (2020) used four proxies of fiscal decentralization, i.e., provincial tax autonomy, provincial local revenue, federal transfers, and total provincial revenue under the revenue approach of fiscal decentralization.

${ }^{5}$ Eyraud \& Lusinyan (2013) used vertical fiscal imbalance to measure the fiscal decentralization in advanced economies. Chalil (2020) used the arithmetic measure of expenditure and revenue decentralization and termed it as a production revenue indicator.
} 


\subsubsection{Control of Corruption}

This reflects the perceptions of the extent to which public power is exercised for private gains, including both petty and grand forms of corruption, as well as "capture" of the state by elites and private interests. The estimate of control of corruption ranges from -2.5 (weak) to 2.5 (strong). Literature has evidenced the role of corruption using a number of macroeconomic indicators, like economic growth (Del Monte \& Papagni, 2001), income inequality (Dincer \& Gunalp, 2012), democracy (Moreno, 2002), and foreign direct investment (Mathur \& Singh, 2013). Therefore, we have included an interaction term of control of corruption and components of fiscal decentralization to determine how control of corruption affects gender equality. It is hypothesized that control of corruption alongside fiscal decentralization increases gender equality in developing economies.

\subsubsection{Government Health Spending}

The government developmental expenditures have implications for gender equality in a number of areas, such as employment, education, health, empowerment, and political participation. Instead of using development expenditures, we have used the health expenditures as a proxy of development expenditures that may directly affect gender equality. Government health spending is measured by domestic general government health expenditure as a percentage of GDP. It is hypothesized that government health spending may increase gender equality in developing economies.

\subsubsection{Female Employment in the Services Sector}

To see the impact of female employment in the services sector on gender equality, it was included in the model. The services sector consists of wholesale and retail trade, restaurants and hotels, transport, storage, communications, financing, insurance, real estate, business services, and community, social, and personnel services. Female workers are employed mostly in the services sectors, while male workers dominate in the industrial and construction sectors. Therefore, we included female employment in the services sector in the analysis to determine its impact on gender equality. It is hypothesized that female employment in the services sector increases gender equality in developing economies.

\subsubsection{GDP Per Capita}

The GDP per capita basically represents the level of development of nations. It is assumed, based on the evidence in the literature, that a nation's level of development corresponds to the level of gender equality. To see the impact of GDP per capita of the economies on gender equality, the log of GDP per capita is included in the model. It is hypothesized that income per capita increases gender equality in developing economies.

\subsection{Source of Data}

The current study used a sample of 29 developing countries that were selected based on the availability of data. The extent of decentralization and socioeconomic dynamics substantially varies across the economies. The impact of decentralization on gender equality may vary among income groups of developing countries, so we divided the economies into two sub-groups-upper-middle income countries and lower-middle income countries ${ }^{6}$. The uppermiddle income economies are Albania, Armenia, Azerbaijan, Bosnia and Herzegovina, Belarus, Brazil, Costa Rica, Colombia, Georgia, Indonesia, Iran, Kazakhstan, Macedonia, Paraguay, Peru, Serbia, South Africa, Thailand, and Turkey. The lower-middle income countries are El Salvador, Honduras, Kenya, Kyrgyzstan, Moldova, Myanmar, Mongolia, Tunisia, Ukraine, and Uganda.

${ }^{6}$ According to the 2019 World Development Report (World Bank, 2019), the lower-middle income economies have a GNI per capita ranging between \$1,026 and $\$ 3,995$, and upper-middle income economies have a GNI per capita ranging between $\$ 3,996$ and $\$ 12,375$. 
The panel data set of gender equality from 2006 to 2020 is taken from Global Gender Gap Report (Hausmann, Laura, \& Saadia, 2012). A linear interpolation method was used to complete the missing data. Data for different measures of fiscal decentralization was taken from the International Monetary Funds' fiscal decentralization database (Victor, William, Clement, Christina, \& JaYuan, 2020). Data on the other control variables, such as government health spending, female employment in services, and GDP per capita, is taken from the World Bank's database (World Bank, 2020), and data on the control of corruption is taken from Daniel \& Aart (2020).

\section{RESULTS AND DISCUSSION}

The descriptive statistics for the sample of developing countries are given in Table 1. It shows that, on average, developing countries focus more on expenditure decentralization compared to revenue decentralization. The control of corruption ranges from -1.8 to 2.1 with mean and standard deviations of -.009 and .919, respectively, in the sample of selected developing countries, which represents that the countries in the sample have a normal range of control of corruption.

Table 1. Descriptive statistics for the sample of developing countries.

\begin{tabular}{c|c|c|c|c|c}
\hline Variable & No. of Observations & Mean & Std. Dev. & Min. & Max. \\
\hline GEN & 435 & 0.6884594 & 0.0383622 & 0.5768 & 0.782 \\
\hline EXPD & 435 & 0.1864132 & 0.1652932 & 0.001059 & 0.8066898 \\
\hline REVD & 435 & 0.0999257 & 0.1010673 & 0.0002709 & 0.5201969 \\
\hline COMPD & 435 & 0.150244 & 0.1843464 & 0.0002712 & 1.084188 \\
\hline COC & 435 & -0.0044717 & 0.9197576 & -1.868714 & 2.169937 \\
\hline GHEXP & 435 & 3.164055 & 1.447504 & 0.173452 & 6.662027 \\
\hline FEMPS & 435 & 50.62885 & 10.83407 & 20.369 & 73.615 \\
\hline LGDPE & 435 & 10.15709 & 0.5857032 & 8.423163 & 11.31628 \\
\hline
\end{tabular}

The results of the system GMM for models 1, 2 and 3 based on equations 2, 3 and 4 for developing economies regarding expenditure decentralization, revenue decentralization, and composite decentralization, respectively, are shown in Table 2. The $p$-values of the Arellano-Bond test for the first order autocorrelation $\operatorname{AR}(1)$ and second order autocorrelation $\mathrm{AR}(2)$ are greater than 0.05 in all three models. Hence, there is no autocorrelation between the residuals of the models, showing that the models are valid.

The p-values of the Sargan test are greater than 0.1, so all models have approved the test of over identifying restriction, hence the validity of the instrumental variables is proved. Additionally, for each model specification, the coefficient of the GEN lag is positively significant at the $1 \%$ level, which indicates a dynamic effect of gender equality.

The results in Table 2 demonstrate that two measures of fiscal decentralization, i.e., revenue decentralization and composite decentralization, have a negative effect on gender equality in developing economies. It negates the general perception as well as the hypothesis of the study. The negative effect of fiscal decentralization on gender equality can be explained through direct and indirect channels. In the direct channel the results explain that the inefficiency and lack of vision and planning at local government levels result in a decrease in gender equality in developing economies. This is based on the argument of Weingast (2014), who inferred that local governments are less effective. Ivanyna \& Shah (2011) argued that decentralization may not always improve social indicators and may even deteriorate them in some cases if local governments are not capable of administering public services competently (Weingast, 2014). The indirect channel may be though the existence of corruption, as at the local government level, corruption hides the advantages decentralization (Nguyen et al., 2020). Shon \& Cho (2020) evidenced that corruption tends to increase in more decentralized structures. Alfada (2019) argued that a higher degree of expenditure facilitates an increase in corruption (Alfano, Baraldi, \& Cantabene, 2019), which may devastate the benefits of fiscal decentralization, even for gender equality. 
Table 2. Results of system GMM for developing economies.

\begin{tabular}{|c|c|c|c|}
\hline \multicolumn{4}{|c|}{ Dependent Variable = GEN (Gender Equality) } \\
\hline Variable & $\begin{array}{c}\text { Model 1 } \\
\text { (Expenditure } \\
\text { Decentralization) }\end{array}$ & $\begin{array}{c}\text { Model } 2 \\
\text { (Revenue } \\
\text { Decentralization) }\end{array}$ & $\begin{array}{c}\text { Model 3 } \\
\text { (Composite } \\
\text { Decentralization) }\end{array}$ \\
\hline GEN L1. & $0.96139(0.000)$ & $0.96716(0.000)$ & $0.96499(0.000)$ \\
\hline EXPD & $0.00094(0.4735)$ & & \\
\hline REVD & & $-0.003401(0.002)$ & \\
\hline COMPD & & & $-0.00139(0.000)$ \\
\hline EXPD*COC & $0.00452(0.000)$ & & \\
\hline REVD*COC & & $0.00851(0.003)$ & \\
\hline COMPD*COC & & & $0.00574(0.000)$ \\
\hline GHEXP & $0.00045(0.001)$ & $0.00038(0.000)$ & $0.00039(0.000)$ \\
\hline FEMPS & $0.00013(0.000)$ & $0.00013(0.002)$ & $0.00013(0.004)$ \\
\hline LGDPE & $-0.00186(0.000)$ & $-0.0015(0.000)$ & $-0.00173(0.000)$ \\
\hline _cons & $0.03936(0.000)$ & $0.03348(0.000)$ & $0.03621(0.000)$ \\
\hline $\mathrm{AR}(1)$ (p-value) & 0.035 & 0.036 & 0.036 \\
\hline $\mathrm{AR}(2)$ (p-value) & 0.052 & 0.054 & 0.053 \\
\hline Sargan test (p-value) & 0.793 & 0.799 & 0.797 \\
\hline No. of Observations & 377 & 377 & 377 \\
\hline
\end{tabular}

However, the interaction between expenditure decentralization and control of corruption, revenue decentralization and control of corruption, and composite decentralization and control of corruption increase gender equality in developing economies. It explains that control of corruption is necessary to increase gender equality in developing economies.

The literature has provided evidence that lack of corruption has desirable impacts on decentralization. Nguyen et al. (2020) suggested that control of corruption and local government effectiveness need to be incorporated with fiscal decentralization to diminish income inequality. Alfada (2019) stated that lack of human capital and low transparency and accountability at the local level enhances the adverse effects of corruption. Decentralization may adversely affect the desirable targets without control of corruption (Chalil, 2020). A commitment to fiscal decentralization needs the vital element of anti-corruption approaches to increase accountability and reduce the preferences of bureaucrats (Steinberg, 2001).

The control variables of the models are health expenditures, female employment in the services sector, and GDP per capita. The idea that government health expenditure reduces the gender gaps in developing economies is supported by the literature. Bein, Unlucan, Olowu, \& Kalifa (2017) showed a positive effect of healthcare expenditure on male and female life expectancies, and that healthcare expenditure has a stronger effect on increasing the life expectancy of females than of males.

Female employment in the services sector has shown a positive impact on gender equality in all three models, implying that female employment in the services sector increases gender equality. Akbulut (2011) demonstrated that female employment increases due to the increased demand of female workers in the domestic services industry. This ultimately increases gender equality. The GDP per capita negatively affects gender equality in all three models for developing economies. This implies the partial fulfilment of Kuznet's hypothesis, i.e., initially, for developing economies, the increase in development/income per capita results in an increase in income inequality. The current study incorporated that increase in income per capita into the increase in gender inequality.

The results of the three models for expenditure decentralization, revenue decentralization, and composite decentralization on gender equity in upper-middle income countries based on equations 2,3 and 4 are reported in Table 3. The $p$-values of $\operatorname{AR}(1)$ and $\operatorname{AR}(2)$ are all greater than 0.1 in all the three models, so no correlation between the residuals of the model exists. The $p$-values of the Sargan test is greater than 0.1 in all models. The coefficient of the GEN lag is positively significant at the $1 \%$ level for each model so there is a dynamic effect of gender equality. 
Similarly, the results of same three models of fiscal decentralization for lower-middle income countries are described in the Table 4. The $p$-values of $\operatorname{AR}(1)$ and $\operatorname{AR}(2)$ exceed 0.1 , hence there is no autocorrelation between the residuals of all three models. The p-values of the Sargan test are also greater than 0.1. Furthermore, for all three models, the GEN lag is negatively significant at the $1 \%$ level, so there is a dynamic persistence effect of gender equality.

Table 3. Results of system GMM for upper-middle income countries.

\begin{tabular}{|c|c|c|c|}
\hline \multicolumn{4}{|c|}{ Dependent Variable = GEN (Gender Equality) } \\
\hline Variable & $\begin{array}{c}\text { Model 1 } \\
\text { (Expenditure } \\
\text { decentralization) }\end{array}$ & $\begin{array}{c}\text { Model } 2 \\
\text { (Revenue } \\
\text { Decentralization) } \\
\end{array}$ & $\begin{array}{c}\text { Model 3 } \\
\text { (Composite } \\
\text { Decentralization) }\end{array}$ \\
\hline GEN L1. & $0.55814(0.000)$ & $0.63919(0.000)$ & $0.59797(0.000)$ \\
\hline EXPD & $-66.48987(0.437)$ & & \\
\hline REVD & & $-339.951(0.000)$ & \\
\hline COMPD & & & $-138.0003(0.000)$ \\
\hline $\mathrm{EXPD} * \mathrm{COC}$ & $380.059(0.000)$ & & \\
\hline REVD*COC & & $597.1992(0.000)$ & \\
\hline $\mathrm{COMPD} * \mathrm{COC}$ & & & $478.7489(0.000)$ \\
\hline GHEXP & $6.1290(0.096)$ & $9.316735(0.029)$ & $2.0922(0.570)$ \\
\hline FEMPS & $10.8257(0.000)$ & $10.17636(0.002)$ & $11.9560(0.004)$ \\
\hline LGDPE & $-97.9883(0.000)$ & $-76.80691(0.000)$ & $-90.1858(0.001)$ \\
\hline _cons & $478.4325(0.081)$ & $303.8831(0.056)$ & $364.729(0.175)$ \\
\hline $\operatorname{AR}(1)(p$-value $)$ & 0.322 & 0.316 & 0.319 \\
\hline $\operatorname{AR}(2)(p$-value) & 0.318 & 0.317 & 0.317 \\
\hline Sargan test ( $p$-value) & 0.396 & 0.313 & 0.330 \\
\hline No. of Observations & 265 & 265 & 265 \\
\hline
\end{tabular}

Table 4. Results of system GMM for lower-middle income countries.

\begin{tabular}{|c|c|c|c|}
\hline \multicolumn{4}{|c|}{ Dependent Variable = GEN (Gender Equality) } \\
\hline Variable & $\begin{array}{c}\text { Model 1 } \\
\text { (Expenditure } \\
\text { Decentralization) }\end{array}$ & $\begin{array}{c}\text { Model } 2 \\
\text { (Revenue } \\
\text { Decentralization) }\end{array}$ & $\begin{array}{c}\text { Model 3 } \\
\text { (Composite } \\
\text { Decentralization) }\end{array}$ \\
\hline GEN L1. & $-0.13757(0.002)$ & $-0.13426(0.001)$ & $-0.13221(0.035)$ \\
\hline EXPD & $0.75239(0.031)$ & & \\
\hline REVD & & 1.89551 (0.056) & \\
\hline COMPD & & & $1.61318(0.040)$ \\
\hline EXPD*COC & $0.59840(0.033)$ & & \\
\hline REVD*COC & & $1.0993(0.033)$ & \\
\hline $\mathrm{COMPD} * \mathrm{COC}$ & & & $1.0461(0.019)$ \\
\hline GHEXP & $-0.08288(0.005)$ & $-0.05124 \quad(0.011)$ & $-0.04576(0.009)$ \\
\hline FEMPS & $0.00835(0.018)$ & $-0.00109(0.782)$ & $-0.00089(0.108)$ \\
\hline LGDPE & $0.09154(0.262)$ & $0.09579(0.308)$ & $0.07652(0.352)$ \\
\hline _cons & $-0.30316(0.001)$ & $-0.01791(0.980)$ & $0.13946(0.823)$ \\
\hline $\operatorname{AR}(1)(p$-values $)$ & 0.307 & 0.305 & 0.307 \\
\hline $\operatorname{AR}(2)(p$-values $)$ & 0.342 & 0.338 & 0.337 \\
\hline Sargan test ( $p$-value) & 0.728 & 0.644 & 0.627 \\
\hline No. of observations & 139 & 139 & 139 \\
\hline
\end{tabular}

For upper-middle income countries, the two measures of fiscal decentralization, i.e., revenue decentralization and composite decentralization, negatively affect gender equality. This is corroborated by the results of developing economies. The explanation may be through the empirical evidence in the literature which shows an aggravating effect of fiscal decentralization.

For instance, Treisman (2000) found that more politically and fiscally decentralized countries suffer from macroeconomic instability. Some studies argued that fiscal decentralization worsens macroeconomic volatility 
(Rodden, 2002; Rodden \& Wibbels, 2002). Similarly, fiscal decentralization may have an adverse impact on macroeconomic stability (Feltenstein \& Iwata, 2005). So, logically, fiscal decentralization through macroeconomic instability may decrease gender equality in upper-middle income economies. However, in all three models, the interaction terms of expenditure decentralization and control of corruption, revenue decentralization and control of corruption, and composite decentralization and control of corruption have shown a positive impact on gender equality in upper-middle income countries. This is also corroborated by the results of developing economies (see Table 2). It states that fiscal decentralization along with control of corruption gives favorable results.

For lower-middle income countries, in all three models, expenditure decentralization, revenue decentralization, and composite decentralization have a positive effect on gender equality. The positive association of fiscal decentralization and gender equality is supported by literature. For instance, Faguet et al. (2021) found that fiscal decentralization improves female health in Ethiopia. Stotsky et al. (2019) found that fiscal decentralization improves gender equality in education in India.

The results of fiscal decentralization and gender equality differ for income groups, i.e., upper-middle income countries and lower-middle income countries. This is supported by the literature on fiscal decentralization's effect on different socioeconomic indicators in various income groups within the economies. For instance, Tselios, Rodríguez-Pose, Pike, Tomaney, \& Torrisi (2011) concluded that the impact of expenditure and revenue decentralization on income inequality differs for low income and high income regions. Similarly, Cavusoglu \& Dincer (2015) evidenced the different effects of expenditure and revenue decentralization on income inequality in low income and high income states. Rodríguez-Pose \& Ezcurra (2010) evidenced regional disparity in developed and developing economies as a result of fiscal decentralization. So, the results of fiscal decentralization for gender equality may differ for income groups among the economies. The difference may be due to varying levels of economies of scale and governance structures, and initial advantageous conditions, in this case, the extreme gender inequality in lower-middle income countries.

The interaction terms of expenditure decentralization and control of corruption, revenue decentralization and control of corruption, and composite decentralization and control of corruption improve gender equality in lowermiddle income economies. This is corroborated by the results of developing economies (see Table 2 ) and the results of upper-middle income economies (see Table 3).

The results explain that fiscal decentralization along with control of corruption increase women's access to education, employment, and income and endow them with greater political rights in upper-middle income countries as well as lower-middle income countries. The effects of the control variables were remarkably different across income groups.

The variable of health expenditure positively affects gender equality in two models for upper-middle income countries, while female employment in the services sector enhances gender equality in all three models in uppermiddle income countries. GDP per capita has shown negative impact on gender equality in all three models for upper-middle income countries. The results of the control variables for upper-middle income countries are corroborated by the results of developing economies. On the other hand, for lower-middle income countries, the health expenditures have shown a negative impact on gender equality in two models, employment of female labor force in the services sector has shown a positive impact on gender equality in one model, and the GDP per capita has shown a statistically insignificant effect on gender equality.

\section{CONCLUSION AND POLICY RECOMMENDATION}

This paper explores the impact of fiscal decentralization on gender equality by using a dynamic panel data analysis. Twenty-nine developing countries were selected for the analysis based on the availability of data and they were divided into two income groups - upper-middle income and lower-middle income. 
This paper concludes that fiscal decentralization cannot improve gender equality in developing economies and upper-middle income countries but it devastates the situation of gender equality in both of these samples, although it has an encouraging effect on gender equality in lower-middle income economies. However, fiscal decentralization may improve gender equality in developing economies and in both income groups of developing economies, i.e., upper-middle income countries and lower-middle income countries, subject to institutional reforms focusing on control of corruption. Otherwise, fiscal decentralization measured by any criteria, such as expenditure decentralization, revenue decentralization, or composite decentralization, adversely affects gender equality in developing economies as well as upper-middle income economies.

Moreover, the effect of fiscal decentralization in lower-middle economies is likely to be more effective than in upper-middle income economies. Therefore, it can be concluded that income groups and corruption in developing economies have a dynamic effect in the implication of fiscal decentralization and gender equality.

Funding: This study received no specific financial support.

Competing Interests: The authors declare that they have no competing interests.

Acknowledgement: Both authors contributed equally to the conception and design of the study.

\section{REFERENCES}

Ahmad, I. (2020). Fiscal decentralisation and economic growth. Pakistan Journal of Applied Economics, 30(1), 95-121.

Akai, N., \& Sakata, M. (2002). Fiscal decentralization contributes to economic growth: evidence from state-level cross-section data for the United States. Journal of Urban Economics, 52(1), 93-108. Available at: https://doi.org/10.1016/s00941190(02)00018-9.

Akbulut, R. (2011). Sectoral changes and the increase in women's labor force participation. Macroeconomic Dynamics, 15(2), 240264. Available at: https://doi.org/10.1017/s1365100510000040.

Alfada, A. (2019). Does fiscal decentralization encourage corruption in local governments? Evidence from Indonesia. Journal of Risk and Financial Management, 12(3), 1-14. Available at: https://doi.org/10.3390/jrfm12030118.

Alfano, M. R., Baraldi, A. L., \& Cantabene, C. (2019). The effect of fiscal decentralization on corruption: A non-linear hypothesis. German Economic Review, 20(1), 105-128. Available at: https://doi.org/10.1111/geer.12164.

Altunbaş, Y., \& Thornton, J. (2012). Fiscal decentralization and governance. Public Finance Review, 4O(1), 66-85.

Arellano, M., \& Bond, S. (1991). Some tests of specification for panel data: Monte Carlo evidence and an application to employment equations. The Review of Economic Studies, 58(2), 277-297. Available at: https://doi.org/10.2307/2297968.

Asfaw, A., Frohberg, K., James, K., \& Jütting, J. (2008). Fiscal decentralization and infant mortality: Empirical evidence from rural India. The Journal of Developing Areas, 41(1), 17-35. Available at: https://doi.org/10.1353/jda.2008.0026.

Atisa, G., Zemrani, A., \& Weiss, M. (2021). Decentralized governments: Local empowerment and sustainable development challenges in Africa. Environment, Development and Sustainability, 23(3), 3349-3367. Available at: https://doi.org/10.1007/s10668-020-00722-0.

Baskaran, T., \& Feld, L. P. (2013). Fiscal decentralization and economic growth in OECD countries: Is there a relationship? Public Finance Review, 4I(4), 42 1-445. Available at: https://doi.org/10.1177/1091142112463726.

Baum, C. F., Schaffer, M. E., \& Stillman, S. (2003). Instrumental variables and GMM: Estimation and testing. The Stata Journal, 3(1), 1-31. Available at: https://doi.org/10.1177/1536867x0300300101.

Bein, M. A., Unlucan, D., Olowu, G., \& Kalifa, W. (2017). Healthcare spending and health outcomes: Evidence from selected East African countries. African Health Sciences, 17(1), 247-254. Available at: https://doi.org/10.4314/ahs.v 17i1.30.

Bianchi, N., Giorcelli, M., \& Martino, E. M. (2021). The effects of fiscal decentralization on publicly provided services and labor markets (January 22, 2021). Available at SSRN: https://ssrn.com/abstract=3407825 or http://dx.doi.org/10.2139/ssrn.3407825. 
Blais, A., Anduiza, E., \& Gallego, A. (2011). Decentralization and voter turnout. Environment and Planning C: Government and Policy, 29(2), 297-320.

Blundell, R., \& Bond, S. (1998). Initial conditions and moment restrictions in dynamic panel data models. Journal of Econometrics, 87(1), 115-143. Available at: https://doi.org/10.1016/s0304-4076(98)00009-8.

Bojanic, A. N. (2018). The impact of fiscal decentralization on accountability, economic freedom, and political and civil liberties in the Americas. Economies, 6(1), 1-20. Available at: https://doi.org/10.3390/economies6010008.

Bojanic, A. N., \& Collins, L. A. (2021). Differential effects of decentralization on income inequality: Evidence from developed and developing countries. Empirical Economics, 60(4), 1969-2004. Available at: https://doi.org/10.1007/s00181-019-018132.

Bond, S. R. (2002). Dynamic panel data models: A guide to micro data methods and practice. Portuguese Economic Journal, 1(2), 141-162. Available at: https://doi.org/10.1007/s 10258-002-0009-9.

Brueckner, J. K. (2000). Fiscal decentralization in developing countries: The effects of local corruption and tax evasion. Annals of Economics and Finance, 1(1), 1-18.

Busemeyer, M. R. (2008). The impact of fiscal decentralisation on education and other types of spending. Swiss Political Science Review, 14(3), 451-481. Available at: https://doi.org/10.1002/j.1662-6370.2008.tbo0109.x.

Cantarero, D., \& Gonzalez, P. P. (2009). Fiscal decentralization and economic growth: Evidence from Spanish regions. Public Budgeting $\Xi^{\circ}$ Finance, 29(4), 24-44. Available at: https://doi.org/10.1111/j.1540-5850.2009.00941.x.

Cantarero, D., \& Pascual, M. (2008). Analysing the impact of fiscal decentralization on health outcomes: Empirical evidence from Spain. Applied Economics Letters, 15(2), 109-111. Available at: https://doi.org/10.1080/13504850600770913.

Cavusoglu, T., \& Dincer, O. (2015). Does decentralization reduce income inequality? Only in rich states. Southern Economic Journal, 82(1), 285-306. Available at: https://doi.org/10.1002/soej.12047.

Chalil, T. M. (2020). Rethinking corruption on fiscal decentralization and global competitiveness Nexus. Competitiveness Review: An International Business Journal, 30(5), 507-527. Available at: https://doi.org/10.1108/cr-04-2019-0039.

Daniel, K., \& Aart, K. (2020). World governance indicator. Retrieved from https://info.worldbank.org/governance/wgi/

Del Monte, A., \& Papagni, E. (2001). Public expenditure, corruption, and economic growth: The case of Italy. European Journal of Political Economy, 17(1), 1-16. Available at: https://doi.org/10.1016/so176-2680(00)00025-2.

Dincer, O. C., \& Gunalp, B. (2012). Corruption and income inequality in the United States. Contemporary Economic Policy, 30(2), 283-292. Available at: https://doi.org/10.1111/j.1465-7287.2011.00262.x.

Duflo, E. (2012). Women empowerment and economic development. Journal of Economic literature, 50(4), 1051-1079. Available at: https://doi.org/10.1257/jel.50.4.1051.

Eyraud, L., \& Lusinyan, L. (2013). Vertical fiscal imbalances and fiscal performance in advanced economies. Journal of Monetary Economics, 60(5), 571-587. Available at: https://doi.org/10.1016/j.jmoneco.2013.04.012.

Faguet, J.-P., Khan, Q., \& Kanth, D. P. (2021). Decentralization's effects on education and health: Evidence from Ethiopia. Publius: The Journal of Federalism, 51(1), 79-103. Available at: https://doi.org/10.1093/publius/pjaa025.

Fan, C. S., Lin, C., \& Treisman, D. (2009). Political decentralization and corruption: Evidence from around the world. Journal of Public Economics, 93(1-2), 14-34. Available at: https://doi.org/10.1016/j.jpubeco.2008.09.001.

Feltenstein, A., \& Iwata, S. (2005). Decentralization and macroeconomic performance in China: Regional autonomy has its costs. Journal of Development Economics, 76(2), 481-501. Available at: https://doi.org/10.1016/j.jdeveco.2004.01.004.

Habibi, N., Huang, C., Miranda, D., Murillo, V., Ranis, G., Sarkar, M., \& Stewart, F. (2003). Decentralization and human development in Argentina. Journal of Human Development, 4(1), 73-101. Available at: https://doi.org/10.1080/1464988032000051496.

Hausmann, R., Laura, D. T., \& Saadia, Z. (2012). The global gender gap report 2009. Geneva: World Economic Forum.

Iimi, A. (2005). Decentralization and economic growth revisited: An empirical note. Journal of Urban Economics, 57(3), 449-461. Available at: https://doi.org/10.1016/j.jue.2004.12.007. 
Iqbal, N., Din, M. U., \& Ghani, E. (2012). Fiscal decentralisation and economic growth: Role of democratic institutions. The Pakistan Development Review, 51(3), 173-195. Available at: https://doi.org/10.30541/v51i3pp.173-195.

Ivanyna, M., \& Shah, A. (2011). Decentralization and corruption: New cross-country evidence. Environment and Planning C: Government and Policy, 29(2), 344-362. Available at: https://doi.org/10.1068/c1081r.

Jalil, A., Feridun, M., \& Sawhney, B. L. (2014). Growth effects of fiscal decentralization: Empirical evidence from China's provinces. Emerging Markets Finance and Trade, 50(4), 176-195. Available at: https://doi.org/10.2753/ree1540$496 \times 500411$.

Khan, S. A. (2011). Decentralization and women empowerment: Exploring the linkages. Journal of Political Studies, 18(1), 61-75. Available at: https://doi.org/10.1080/12294659.2013.10805256.

Koethenbuerger, M., \& Lockwood, B. (2010). Does tax competition really promote growth? Journal of Economic Dynamics and Control, 34(2), 191-206. Available at: https://doi.org/10.1016/j.jedc.2009.09.001.

Li, X., Younas, M. Z., Andlib, Z., Ullah, S., Sohail, S., \& Hafeez, M. (2021). Examining the asymmetric effects of Pakistan's fiscal decentralization on economic growth and environmental quality. Environmental Science and Pollution Research, 28(5), 5666-5681. Available at: https://doi.org/10.1007/s11356-020-10876-z.

Lin, J. Y., \& Liu, Z. (2000). Fiscal decentralization and economic growth in China. Economic Development and Cultural Change, $49(1), 1-21$.

Malik, S., \& Hussain, S. (2006). Fiscal decentralisation and economic growth in Pakistan. The Pakistan Development Revierw, 45(4II), 845-854. Available at: https://doi.org/10.30541/v45i4iipp.845-854.

Martinez-Vazquez, J., \& McNab, R. M. (2003). Fiscal decentralization and economic growth. World Development, 31(9), 15971616.

Martinez-Vazquez, J., \& Timofeev, A. (2009). A fiscal perspective of state rescaling. Cambridge Journal of Regions, Economy and Society, 2(1), 85-105. Available at: https://doi.org/10.1093/cjres/rsno27.

Martinez-Vazquez, J., \& Yao, M.-H. (2009). Fiscal decentralization and public sector employment: A cross-country analysis. Public Finance Review, 37(5), 539-571. Available at: https://doi.org/10.1177/1091142109343176.

Mathur, A., \& Singh, K. (2013). Foreign direct investment, corruption and democracy. Applied Economics, 45(8), 991-1002. Available at: https://doi.org/10.1080/00036846.2011.613786.

Moreno, A. (2002). Corruption and democracy: A cultural assessment. Comparative Sociology, 1(3-4), 495-507. Available at: https://doi.org/10.1163/156913302100418556.

Neyapti, B. (2010). Fiscal decentralization and deficits: International evidence. European Journal of Political Economy, 26(2), 155166. Available at: https://doi.org/10.1016/j.ejpoleco.2010.01.001.

Nguyen, L. P., \& Anwar, S. (2011). Fiscal decentralisation and economic growth in Vietnam. Journal of the Asia Pacific Economy, $16(1), 3-14$.

Nguyen, H. T., Thuy, H. N. V., Duc, D. M. L., \& Vu, T. N. (2020). Fiscal decentralization, corruption, and income inequality: Evidence from Vietnam. Journal of Asian Finance, Economics and Business, 7(11), 529-540. Available at: https://doi.org/10.13106/jafeb.2020.vol7.no11.529.

Nussbaum, M. C. (2011). Capabilities, entitlements, rights: Supplementation and critique. Journal of Human Development and Capabilities, 12(1), 23-37. Available at: https://doi.org/10.1080/19452829.2011.541731.

Oates, W. E. (1993). Fiscal decentralization and economic development. National Tax Journal, 46(2), 237-243.

Oates, W. E. (1999). An essay on fiscal federalism. Journal of Economic Literature, 37(3), 1120-1 149.

Paramita, S. A., Yamazaki, C., Setiawati, E. P., \& Koyama, H. (2018). Distribution trends of Indonesia's health care resources in the decentralization era. The International Journal of Health Planning and Management, 33(2), e586-e596. Available at: https://doi.org/10.1002/hpm.2506.

Prud'Homme, R. (1995). The dangers of decentralization. The World Bank Research Observer, 1O(2), 201-220. Available at: https://doi.org/10.1093/wbro/10.2.201. 
Qian, Y., \& Weingast, B. R. (1997). Federalism as a commitment to reserving market incentives. Journal of Economic Perspectives, 11(4), 83-92. Available at: https://doi.org/10.1257/jep.11.4.83.

Rodden, J. (2002). The dilemma of fiscal federalism: Grants and fiscal performance around the world. American Journal of Political Science, 46(3), 670-687. Available at: https://doi.org/10.2307/3088407.

Rodden, J., \& Wibbels, E. (2002). Beyond the fiction of federalism: Macroeconomic management in multitiered systems. World Politics, 54(4), 494-531. Available at: https://doi.org/10.1353/wp.2002.0016.

Rodríguez-Pose, A., \& Ezcurra, R. (2010). Does decentralization matter for regional disparities? A cross-country analysis. Journal of Economic Geography, 1O(5), 619-644. Available at: https://doi.org/10.1093/jeg/lbp049.

Rodríguez-Pose, A., \& Krøijer, A. (2009). Fiscal decentralization and economic growth in Central and Eastern Europe. Growth and Change, 4O(3), 387-417. Available at: https://doi.org/10.1111/j.1468-2257.2009.00488.x.

Rodriguez-Pose, A., Tomaney, J., Pike, A., Torrisi, G., \& Tselios, V. (2011). Income inequality, decentralisation, and regional development in Western Europe. Environment and Planning A, 44(6), 1278-1301. Available at: https://doi.org/10.1068/a44334.

Rubio, D. J. (2011). The impact of decentralization of health services on health outcomes: Evidence from Canada. Applied Economics, 43(26), 3907-3917. Available at: https://doi.org/10.1080/00036841003742579.

Sen, A. (2000). Development as freedom. Development in Practice, 10(2), 258-258.

Sepulveda, C. F., \& Martinez-Vazquez, J. (2011). The consequences of fiscal decentralization on poverty and income equality. Environment and Planning C: Government and Policy, 29(2), 32 1-343. Available at: https://doi.org/10.1068/c1033r.

Shon, J., \& Cho, Y. K. (2020). Fiscal decentralization and government corruption: Evidence from US states. Public Integrity, 22(2), 187-204. Available at: https://doi.org/10.1080/10999922.2019.1566427.

Soejoto, A., Subroto, W. T., \& Suyanto, Y. (2015). Fiscal decentralization policy in promoting Indonesia human development. International Journal of Economics and Financial Issues, 5(3), 763-771.

Steinberg, F. (2001). Helping countries combat corruption-progress at the world bank since 1997. Habitat International, 25(4), 617-618. Available at: https://doi.org/10.1016/s0197-3975(00)00039-4.

Stotsky, J. G., Chakraborty, L., \& Gandhi, P. (2019). Impact of intergovernmental fiscal transfers on gender equality in India: An empirical analysis. Working Paper No. 1/2019. Canberra: Tax and Transfer Policy Institute. Australian National University.

Thomson, K., Hillier-Brown, F., Todd, A., McNamara, C., Huijts, T., \& Bambra, C. (2018). The effects of public health policies on health inequalities in high-income countries: An umbrella review. BMC Public Health, 18(1), 1-21. Available at: https://doi.org/10.1186/s12889-018-5677-1.

Tiebout, C. M. (1956). A pure theory of local expenditures. Journal of Political Economy, 64(5), 416-424. Available at: https://doi.org/10.1086/257839.

Treisman, D. (2000). Decentralization and inflation: Commitment, collective action, or continuity? American Political Science Review, 94(4), 837-857. Available at: https://doi.org/10.2307/2586211.

Tselios, V., Rodríguez-Pose, A., Pike, A. J., Tomaney, J., \& Torrisi, G. (2011). Income inequality, decentralisation and regional development in western Europe. (CEPR Discussion Paper No. 8575).

Victor, L., William, G., Clement, N., Christina, H., \& JaYuan, X. (2020). The IMF fiscal decentralization dataset. Retrieved from https://data.imf.org/?sk=388dfa60-1d26-4ade-b505-a05a558d9a42\&sId=1479329132316

Wang, K.-H., Liu, L., Adebayo, T. S., Lobon, O.-R., \& Claudia, M. N. (2021). Fiscal decentralization, political stability and resources curse hypothesis: A case of fiscal decentralized economies. Resources Policy, 72, 102071. Available at: https://doi.org/10.1016/j.resourpol.2021.102071.

Weingast, B. R. (2014). Second generation fiscal federalism: Political aspects of decentralization and economic development. World Development, 53, 14-25. Available at: https://doi.org/10.1016/j.worlddev.2013.01.003.

World Bank. (2019). World development report 2019: The changing natue of work. Washington, DC: The World Bank. 
World Bank. (2020). World development indicators. Retrieved from https://databank.worldbank.org/source/worlddevelopment-indicators.

Xie, D., Zou, H.-F., \& Davoodi, H. (1999). Fiscal decentralization and economic growth in the United States. Journal of Urban Economics, 45(2), 228-239. Available at: https://doi.org/10.1006/juec.1998.2095.

Zhang, T., \& Zou, H.-F. (1998). Fiscal decentralization, public spending, and economic growth in China. Journal of Public Economics, 67(2), 22 1-240. Available at: https://doi.org/10.1016/s0047-2727(97)00057-1.

Views and opinions expressed in this article are the views and opinions of the author(s), Asian Economic and Financial Review shall not be responsible or answerable for any loss, damage or liability etc. caused in relation to/arising out of the use of the content. 